\title{
Polychlorinated Biphenyls in Whole-Body Field Mice Collected Upgradient and Downgradient of a Sediment Retention Structure in Los Alamos Canyon, Los Alamos National Laboratory, New Mexico, USA
}

\author{
Philip R. Fresquez \\ Environmental Stewardship Group, Los Alamos National Laboratory, Los Alamos, USA. \\ Email: fresquezp@lanl.gov
}

Received November $23^{\text {rd }}$, 2013; revised December $24^{\text {th }}$, 2013; accepted January $22^{\text {nd }}, 2014$

Copyright (C) 2014 Philip R. Fresquez. This is an open access article distributed under the Creative Commons Attribution License, which permits unrestricted use, distribution, and reproduction in any medium, provided the original work is properly cited. In accordance of the Creative Commons Attribution License all Copyrights (C) 2014 are reserved for SCIRP and the owner of the intellectual property Philip R. Fresquez. All Copyright (C) 2014 are guarded by law and by SCIRP as a guardian.

\section{ABSTRACT}

Polychlorinated biphenyl (PCBs) congeners were measured in (unwashed) whole-body field (deer) mice (Peromyscus maniculaltus) collected directly upgradient from a sediment retention structure (weir) within Los Alamos Canyon (LAC), Los Alamos National Laboratory (LANL), New Mexico, USA, from 2007 through 2013. Samples were also collected approximately $8 \mathrm{~km}$ downgradient of the retention structure in 2009 and 2013. LAC, a major drainage that crosses LANL lands, contains legacy waste, including PCBs, and occasionally discharges storm water and snowmelt flows to the Rio Grande approximately $8.8 \mathrm{~km}$ away from the weir. The Rio Grande is the major waterway that flows southward across the state. The weir was constructed across the channel on the northeastern boundary of LANL in late 2000 to help contain sediments mobilized by floodwaters as a result of a large wildfire in early 2000 that burned forest lands west and adjacent to LANL. Total PCBs in field mice directly upgradient of the sediment retention structure from 2007 through 2012 were significantly greater $(p<0.05)$ than in field mice collected from background locations but decreased in concentration over time; by 2013 the levels were statistically similar $(p>0.05)$ to background. The highest mean total PCB concentration in field mice was below the levels that may negatively impact field mice population attributes. Total PCBs in field mice collected $8 \mathrm{~km}$ below the sediment retention structure in 2009 were lower than field mice collected from behind the weir and decreased over time; also by 2013, the amount of PCBs in field mice $8 \mathrm{~km}$ below the sediment retention structure were not significantly different $(p>0.05)$ from background. The rank order of concentrations of ICES 7 PCB congeners in upgradient and downgradient field mice were: No. $153>180>138>118>28>101>52$ and No. $153>180>138>118>28>52>101$, respectively. Based on the PCB homolog distribution, the major formulation detected in field mice was Aroclor-1260. Overall, the reduction of PCBs in whole-body field mice from both sites over time was attributed, in part, to sediment control practices.

\section{KEYWORDS}

Polychlorinated Biphenyl Congeners; Deer Mice; Peromyscus; Biomonitoring; Rio Grande; Southwest; New Mexico

\section{Introduction}

Polychlorinated biphenyls (PCBs) represent one of the most persistent and toxic groups of contaminants in the environment because of their stable properties and ubiquitous distribution [1]. They were manufactured in the
United States between 1930 and 1976 [2] and were developed predominantly for use as coolants and lubricants because of their general chemical inertness and heat stability in electrical equipment such as capacitors and transformers [3]. Also, they have been used in oil in mo- 
tors and hydraulic systems, flame retardants, inks, adhesives, carbonless copy paper, paints, wood-floor finishes, pesticide extenders, plasticizers, polyolefin catalyst carriers, slide-mounting mediums for microscopes, surface coatings, wire insulators, and metal coatings. Aroclor was the trade name for technical mixtures of PCBs manufactured in the United States. Nine Aroclor mixtures were produced with the bulk being Aroclor-1016 (13\%), -1242 (52\%), -1248 (7\%), -1254 (16\%), and -1260 (11\%); each contains a specific mixture of 209 congeners. A congener is a specific PCB compound with a certain number of chlorine atoms in certain positions around a biphenyl ring [4]. With respect to their behavior in the environment, PCBs are hydrophobic, accumulate in sediment, lipophilic, and bioaccumulate and biomagnify along food chains $[1,5,6]$.

Field mice are effective biomonitors of environmental contamination because of their ubiquitous distribution, relative abundance, ease of collection, feeding habits, association with the soil (e.g., burrowing), and limited home range ( 0.036 to 0.61 hectares) ( 0.089 to 1.5 acres) [7-11]. The degree of radionuclide [8,12-14], heavy metal [10,15-17], high explosive [18], dioxin/furan [19,20], and PCB $[10,20-25]$ concentrations in field mice has been evaluated around various waste sites. With respect to PCBs, studies have shown that the amounts of PCBs differ between small mammal species varying in foraging strategies $[10,23]$ and high levels of PCBs were reported to cause population alterations (e.g., abundance and species composition) [24-29]. Impaired growth and development, survivorship, and abnormalities in liver tissues have been shown to occur in laboratory mice when exposed to $10-100 \mathrm{mg} / \mathrm{kg}$ of PCBs in the diet $[26,30]$ and a reduction in field mice populations as a result of decreased reproductive capabilities and changes in liver, spleen and adrenal functions were observed in (whole body) field mice containing an average of $2.5 \mathrm{mg} / \mathrm{kg}$ wet of PCBs [22].

Los Alamos National Laboratory (LANL), a multidisciplinary research institution established in 1943, is situated on a large mesa with many deep, mostly ephemeral, west-to-east-oriented drainage canyons (Figure 1). During the early years of LANL operations (mostly nuclear weapons work), some of these canyon drainage systems received various amounts of radioactive and chemical waste effluents from outfalls [31,32]. Of the major drainages that cross LANL lands, the Los Alamos Canyon (LAC) drainage system has been identified as containing some of the highest amounts of radionuclides and metals [33,34]. LAC also contains PCBs; total PCBs in 2004-2005, for example, were reported to be as high as $100 \mathrm{mg} / \mathrm{kg}$ on the hillsides of upper LAC and approximately 0.50 and $0.20 \mathrm{mg} / \mathrm{kg}$ in suspended sediments within the watercourse collected further downgradient at mid- and lower reaches of LAC, respectively [35]. Aroclor $1254(20 \%)$ and $-1260(80 \%)$ mixtures were mostly detected [36,37]. Moreover, LAC has the highest potential of transporting these chemicals via storm water and snow melt to the Rio Grande which is approximately 8.8 $\mathrm{km}(5.5 \mathrm{mi})$ away from the northeast boundary of LANL [38]. The Rio Grande is the main drainage in New Mexico and traverses approximately 1207 river kilometers from its headwater in the San Juan Mountains in southwestern Colorado, southward through the entire State of New Mexico, to El Paso, Texas [39]. Mercury and PCBs are the two main contaminants found in fish in the Rio Grande in northern New Mexico; the major source(s) are upstream relative to LANL $[40,41]$.

In May of 2000, a prescribed burn at Bandelier National Monument, New Mexico, USA, went out of control and burned nearly 20,000 hectares (50,000 acres) in a south to northeast direction on primarily Federal and Native American Pueblo lands (the Cerro Grande Fire), including approximately 3038 hectares (7500 acres) on LANL property. Eleven years later in June of 2011 another large wildfire (the Las Conchas Fire) burned nearly 65,000 hectares (161,000 acres), including portions of areas recovering from the Cerro Grande Fire. The lack of vegetative cover in the wake of the first fire (Cerro Grande Fire) created concerns regarding increased sediment transport from LANL to offsite locations. As a preventive measure, a gabion rock-filled, low-head weir was constructed in late 2000 across the channel in LAC near the northeastern boundary of LANL to reduce the transport of sediments to the Rio Grande (Figure 2) [42]. The retention basin encompasses over 0.41 hectares ( 1 acre) in area and blocks over one-half of the sediment load from reaching the Rio Grande [35]; it was excavated of sediments prior to the rainy season in 2009, 2011, and 2013.

The objective of this study was to determine PCB (congener) concentrations in whole-body field mice upgradient and downgradient of the LAC sediment retention structure over time. The downgradient site is approximately $8 \mathrm{~km}(5 \mathrm{mi})$ below the retention structure and receives flow from LAC, Pueblo Canyon, and a few other tributaries not related to LANL property. Pueblo Canyon joins LAC approximately $1.0 \mathrm{~km}(0.62 \mathrm{mi})$ downgradient of the weir and also contains legacy (and Los Alamos town site) waste including PCBs but in much lower concentrations [36,37]. Results of radionuclides and metals in field mice collected from behind the retention structure have been previously reported $[43,44]$.

\section{Methods and Materials}

As part of the Environmental Surveillance Program at 


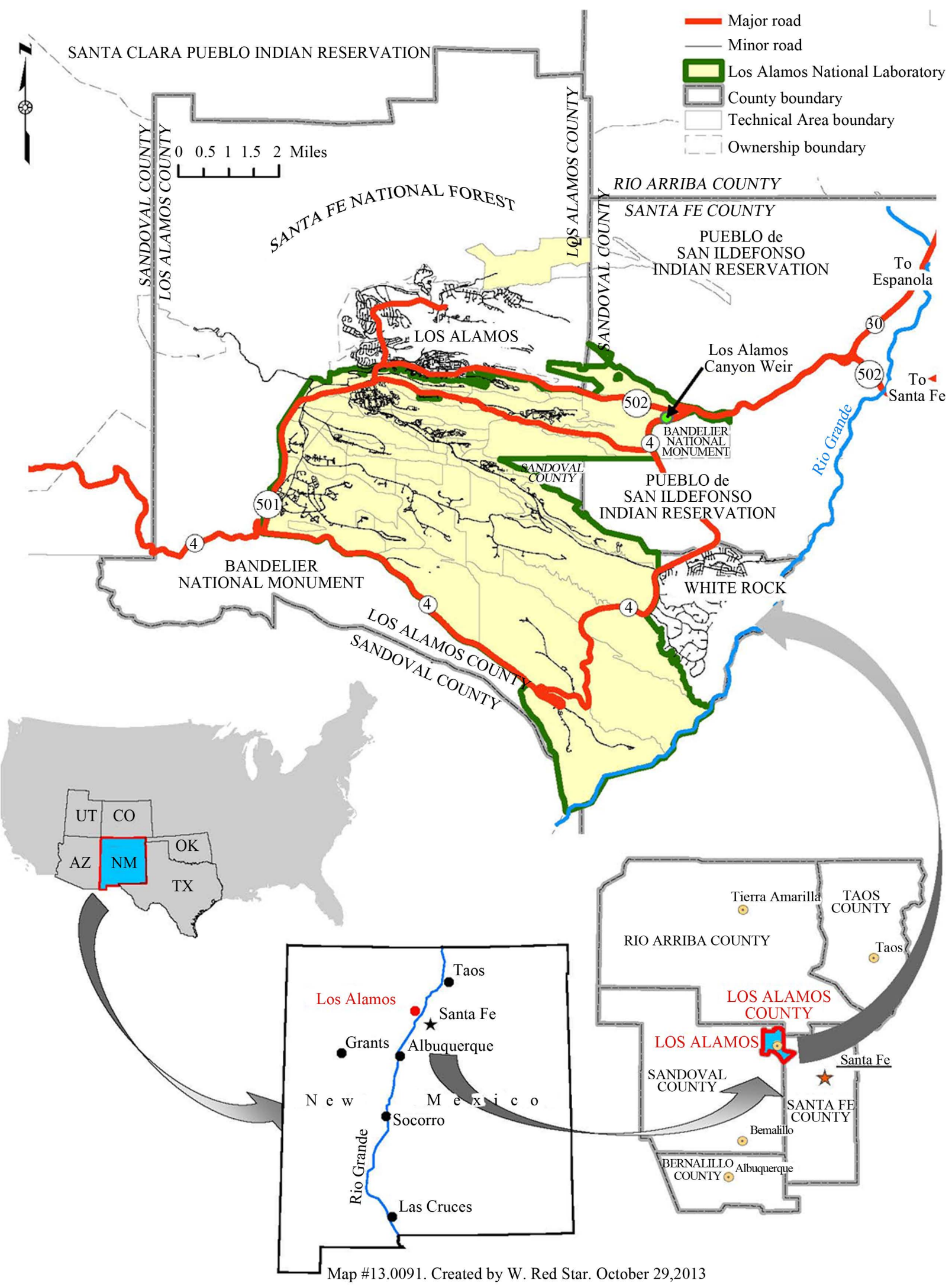

Figure 1. Location of Los Alamos Canyon Weir, Los Alamos National Laboratory, New Mexico, USA. 


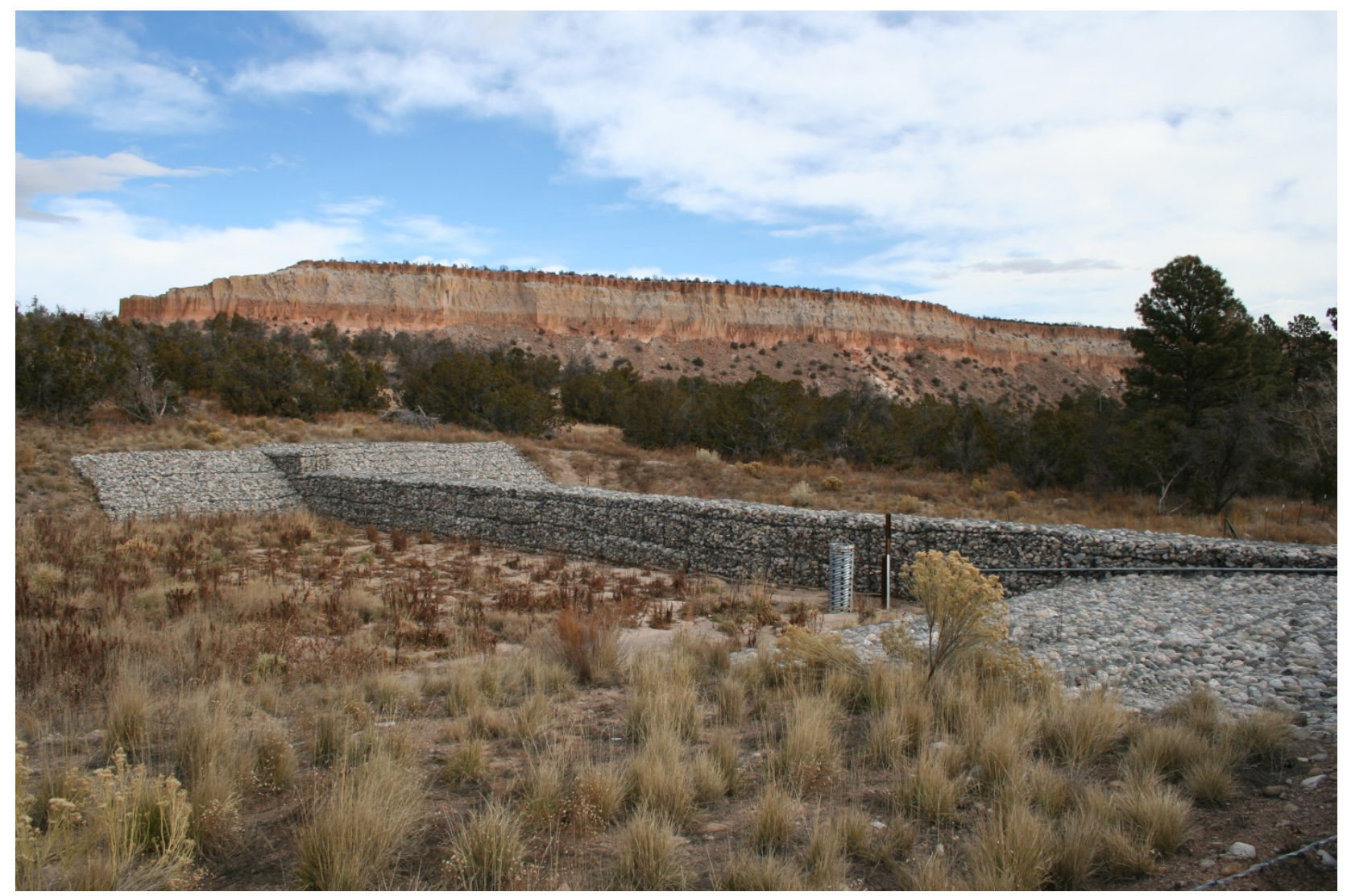

Figure 2. The Los Alamos Canyon sediment retention structure (upgradient side) in 2005 near the northeastern boundary of Los Alamos National Laboratory.

LANL, from one to five sediment samples were collected periodically from behind the LAC retention basin from 2003 through 2013; each sample was collected with a Teflon scoop at the 0 - to 16-cm depth; placed into an 500 $\mathrm{mL}$ amber glass jar; and submitted frozen to the General Engineering Laboratory (Charleston, SC) for the analysis of PCB Aroclors. PCBs were extracted and analyzed according to Solid Waste (SW) -846 Environmental Protection Agency (EPA) Method 8082 (Aroclors by Gas Chromatography). Only Aroclor-1254 and -1260 were detected in any significant quantities; all other Aroclors were not found or were detected in trace amounts.

Deer mice (Peromyscus maniculatus), an omnivore, were collected from traps set along the edges and middle of the LAC retention basin in May-July (generally 2-3 months after excavation in 2009, 2011 and 2013, and before the rainy season) from 2007 through 2013 and approximately $8 \mathrm{~km}$ downgradient of the weir in 2009 and 2013. Snap traps and Sherman live traps were used to collect the mice from 2007 through 2011 and from 2012 through 2013, respectively. The switch to Sherman live traps in the latter years was to reduce the incidence of bird mortalities. All traps were baited with a peanut butter and oat combination and set under vegetation in the late afternoon and checked in the early morning. Collections adhered to strict hantavirus protocols $[45,46]$ and field mice collected using the Sherman live traps were euthanized using an isoflourine chemical. A cotton ball containing isoflourine was placed inside a small plastic vial with holes; the vial was then placed inside a Ziplock bag containing the mouse sample.

Three mice per year were collected for the analysis of 209 possible PCB congeners; each (unwashed) wholebody (pelt plus carcass) sample was placed into a labeled 250-mL amber glass jar and analyzed by SW-846 EPA Method 1668A (Congeners by High Resolution Gas Chromatography/High Resolution Mass Spectrometry) by Vista Analytical Laboratory (El Dorado Hill, CA) from 2007-2009 and by Cape Fear Analytical (Wilmington, NC) from 2010-2013. For summary purposes, PCB congeners were grouped together into 10 homologs; a homolog is a group of congeners with the same number of chlorine atoms, which allows visual comparison of similarities or differences between samples or groups of samples. The designations for the 10 homologs range from monochlorobiphenyl (monoCB) to decachlorobiphenyl (decaCB). Homologs and total PCBs are reported on a pg/g (parts per trillion) wet weight basis. Concentra- 
tions of PCBs in field mice collected upgradient and downgradient of the LAC weir were statistically compared with PCB concentrations from field mice collected from regional background areas $(\mathrm{n}=12)$ away from the influence of LANL [47] using a Mann-Whitney U (nonparametric) test at the 0.05 probability level. Background field mice were mostly comprised of deer mice, but also included a few other omnivore species such as the pinyon mouse (Peromyscus truie) and pocket mouse (Chaetodipus penicillatus). Four background field mice were collected approximately $42 \mathrm{~km}$ north of LANL from a grassland site in 2008 (Medanales, NM); four were collected approximately $13 \mathrm{~km}$ east of LANL from a grassland site in 2009 (Pueblo de San Ildefonso, NM); one was collected approximately $26 \mathrm{~km}$ east of LANL from an urban garden site in 2011 (Nambe, NM); and three were collected approximately $23 \mathrm{~km}$ northeast of LANL from an arroyo site in 2013 (Española, NM). In general, the order of total PCBs in these samples were: arroyo > grassland $>$ garden.

\section{Results and Discussion}

Mean concentrations of Aroclor-1254 and -1260 detected in surface sediment samples collected from behind the sediment retention basin from 2003 through 2013 are shown in Table 1. In general, mean concentrations of Aroclor-1260 were detected in higher concentrations than Aroclor-1254 with the highest amount peaking in 2007; after that, concentrations of both PCB formulations gradually decrease to nondetectable amounts in the latter years. The highest combined total amount detected in sediments behind the LAC weir (230 $\mu \mathrm{g} / \mathrm{kg}$ in 2006) is two orders of magnitude below the amounts shown in

Table 1. Polychlorinated Biphenyl Aroclor-1254 and -1260 Concentrations $(\mu \mathrm{g} / \mathrm{kg})$ in Surface Sediments Collected Behind the Los Alamos Canyon Retention Structure from 2003 through 2013.

\begin{tabular}{ccc}
\hline & \multicolumn{2}{c}{ Aroclor } \\
\cline { 2 - 3 } Month/Year & 1254 & 1260 \\
\hline $8 / 2003$ & 27 & 27 \\
$4 / 2006$ & 120 & 110 \\
$9 / 2006$ & $\mathrm{U}^{*}$ & 180 \\
$6 / 2007$ & $\mathrm{U}$ & 220 \\
$5 / 2008$ & 29 & 24 \\
$9 / 2008$ & 29 & 36 \\
$12 / 2010$ & $\mathrm{U}$ & $\mathrm{U}$ \\
$1 / 2013$ & $\mathrm{U}$ & $\mathrm{U}$ \\
\hline
\end{tabular}

${ }^{*} \mathrm{U}=$ undetected below the MDL $(2.0 \mu \mathrm{g} / \mathrm{kg})$. field mice diets under laboratory conditions to negatively affect growth and development, survivorship, and abnormalities in liver tissues in mice $(10,000-100,000$ $\mu \mathrm{g} / \mathrm{kg}$ ) [26,30]; and below the ecological (soil) screening level of $20,000 \mu \mathrm{g} / \mathrm{kg}$ for the deer mouse for Aroclor-1260 [48]. The ecological screening level is the total concentration of Aroclor-1260 in the soil that is not expected to produce any adverse effects on (omnivore) field mice that come into contact with the soil or ingest biota that live in or on the soil (i.e., it is the concentration that is protective of the receptor under chronic exposure conditions).

Total PCB concentrations in whole-body field mice collected from behind the LAC sediment retention structure from 2007 through 2012 were significantly higher (p $<0.05$ ) than field mice collected from background locations (Table 2); however, the levels generally decreased over time (Figure 3), and by 2013, the concentrations of PCBs in field mice collected from behind the LAC weir were statistically similar $(p>0.05)$ to background. The increase in total PCBs in field mice from 2007 to 2008 may be a result of some influx of contamination-laden sediments from flooding events that occurred the prior year; the levels subsequently decreased the following year probably because of the removal of sediments in 2009 prior to sampling. Field mice collected in 2009, 8 $\mathrm{km}$ below the LAC sediment retention structure, were generally lower (statistically different at $\mathrm{p}<0.10$ ) in total PCBs than field mice collected from behind the LAC weir but still significantly higher $(\mathrm{p}<0.05)$ than background. By 2013, however, the concentrations of total PCBs in field mice collected $8 \mathrm{~km}$ below the LAC weir were statistically similar $(\mathrm{p}>0.05)$ to background.

Although the PCB levels in field mice collected upgradient of the LAC weir in most years were statistically higher than background, the concentrations were considerably lower than other studies of PCB contamination in small mammals at waste and control sites [10,21-25]. More importantly, most amounts are not high enough to indicate extensive bioaccumulation in these short-lived animals [21] and the highest average amount detected $\left(8.6 \times 10^{4} \mathrm{pg} / \mathrm{g}\right.$ wet) was two orders of magnitude below the average whole-body amount $\left(2.5 \times 10^{6} \mathrm{pg} / \mathrm{g}\right.$ wet $)$ that may result in negative attributes to field mice populations [22].

The decrease in total PCB concentrations in wholebody field mice (and sediment) collected from behind the LAC sediment retention basin over time may be related to one or more of the sediment-control practices employed by LANL. These practices include the removal of source materials, rerouting storm water away from areas of known contamination, sediment traps, check dams, mulching, and vegetative plantings [49]. As mentioned 
Table 2. Mean Total Homolog and PCB Concentrations (pg/g wet \pm standard deviation) in Whole-Body Field Mice Collected Upgradient (UG) and 8 km Downgradient (DG) of a Sediment Retention Basin from 2007 through 2013 in Los Alamos Canyon, Los Alamos National Laboratory, New Mexico, USA.

\begin{tabular}{|c|c|c|c|c|c|c|c|c|c|c|}
\hline \multirow{2}{*}{ Homolog } & \multirow{2}{*}{$\begin{array}{c}2007 \\
\text { UG }\end{array}$} & \multirow{2}{*}{$\begin{array}{c}2008 \\
\text { DG }\end{array}$} & \multicolumn{2}{|c|}{2009} & \multirow{2}{*}{$\begin{array}{c}2010 \\
\text { UG }\end{array}$} & \multirow{2}{*}{$\begin{array}{c}2011 \\
\text { UG }\end{array}$} & \multirow{2}{*}{$\frac{2012}{\text { UG }}$} & \multicolumn{2}{|c|}{2013} & \multirow{2}{*}{$\begin{array}{c}\text { Regional } \\
\text { Background }\end{array}$} \\
\hline & & & UG & DG & & & & UG & DG & \\
\hline MonoCB & 0.0 & 0.0 & 0.0 & 0.0 & 0.0 & 0.0 & 0.0 & 0.0 & 0.0 & 0.0 \\
\hline DiCB & 12 & 6.1 & 14 & 37 & 0.0 & 0.0 & 7.7 & 5.8 & 18 & 54 \\
\hline TriCB & 17 & 0.9 & 0.0 & 0.0 & 0.0 & 0.0 & 11 & 0.0 & 26 & 37 \\
\hline TetraCB & 84 & 82 & 2.3 & 0.0 & 0.0 & 8.0 & 11 & 2.1 & 51 & 13 \\
\hline PentaCB & 585 & 3027 & 396 & 102 & 262 & 492 & 120 & 55 & 15 & 11 \\
\hline НехаСВ & 7817 & 31773 & 8937 & 1122 & 8060 & 3226 & 1390 & 1288 & 471 & 91 \\
\hline HeptaCB & 9907 & 40967 & 12460 & 1046 & 10787 & 3190 & 1781 & 1582 & 400 & 88 \\
\hline OctaCB & 2250 & 9033 & 4550 & 355 & 1976 & 665 & 557 & 371 & 175 & 65 \\
\hline NonaCB & 138 & 532 & 273 & 31 & 172 & 73 & 51 & 39 & 17 & 25 \\
\hline DecaCB & 12 & 36 & 24 & 2.6 & 12 & 5.3 & 2.2 & 4.6 & 2.9 & 7.8 \\
\hline Total PCB ${ }^{*}$ & $\begin{array}{c}\text { 20798A } \\
\text { (5175) }\end{array}$ & $\begin{array}{l}85663 \mathrm{~A} \\
(65314)\end{array}$ & $\begin{array}{c}\text { 26667Aa } \\
(6341)\end{array}$ & $\begin{array}{c}2701 \mathrm{Aa} \\
(1727)\end{array}$ & $\begin{array}{l}21256 \mathrm{~A} \\
(12102)\end{array}$ & $\begin{array}{l}\text { 7657A } \\
(5577)\end{array}$ & $\begin{array}{l}3932 A \\
(2794)\end{array}$ & $\begin{array}{c}\text { 3346Bb } \\
(2252)\end{array}$ & $\begin{array}{c}\text { 1175Bb } \\
(1256)\end{array}$ & $\begin{array}{l}392 B \\
(290)\end{array}$ \\
\hline
\end{tabular}

*Total PCB means within the same row followed with the same upper case letter are not significantly different from background at the 0.05 level by a Mann-Whitney U test. Means in 2009 and 2013 in the same row between locations in the same year followed by the same lower case letter are not significantly different from one another at the 0.05 level by a Mann-Whitney U Test.

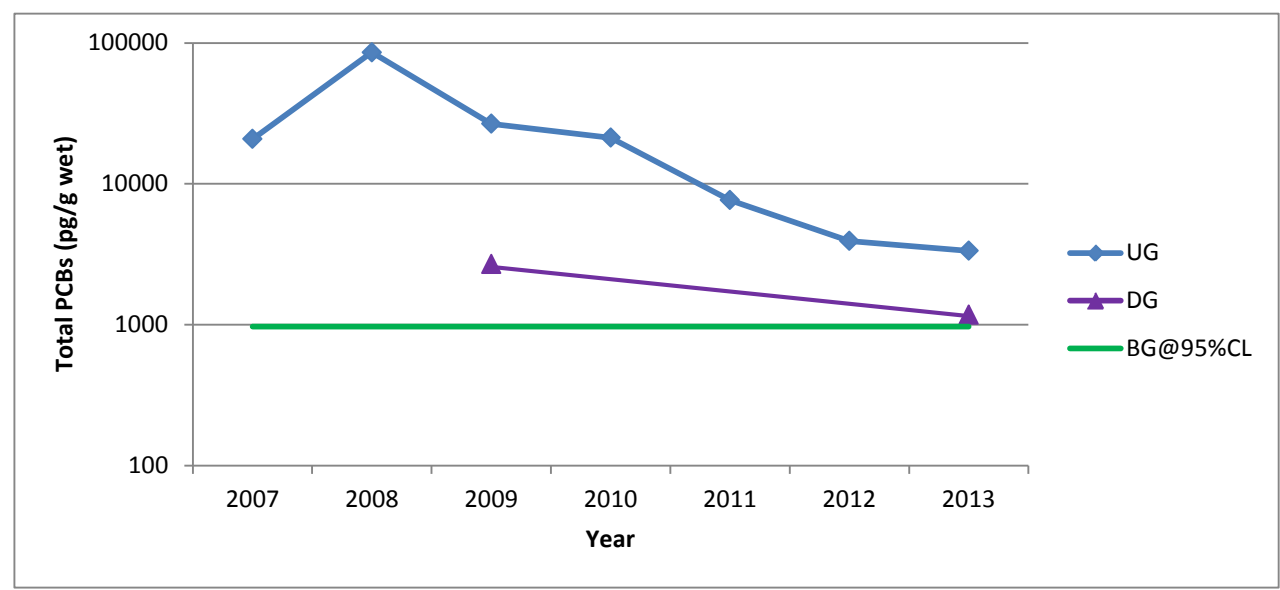

Figure 3. The mean total PCB concentrations in whole-body field mice collected directly upgradient (UG) and 8 km downgradient (DG) of the LAC sediment retention structure from 2007 through 2013 as compared to background (BG) at the $95 \%$ confidence (upper) level (mean plus two standard deviations).

earlier, sediments on three occasions (2009, 2011 and 2013) were excavated and removed from the weir basin prior to sampling. Moreover, the impediment of at least one-half of the sediment load by the LAC sediment retention basin itself [35] may have been partly responsible for the even lower amounts of PCBs in field mice $8 \mathrm{~km}$ downgradient of the LAC weir in 2009 and 2013 as compared to upgradient amounts. Natural fluvial processes over time, including the adsorption of contaminants to sediment/organic materials, subsequent flooding and the redistribution and mixing of (non-contaminated) sediments from other sources, and distance from the source may also have played a role in the lower PCB levels in field mice [36,37]. By 2013, PCB levels in field mice collected from both up- and down-gradient sites were statistically similar to background.

Based on the seven PCB congeners known as the ICES 7 that are recommended for routine environmental monitoring (No. 28, 52, 101, 118, 138, 153 and 180) [50,51], the congeners in rank order in (unwashed) whole-body 
field (deer) mice from behind and below the LAC retention structure were No. $153>180>138>118>28>$ $101>52$ and No. $153>180>138>118>28>52>$ 101, respectively. These congeners were generally similar to those detected in other field mice species that have similar foraging behaviors (e.g., omnivores). Smith et al. [10] reported selected PCB congener levels in liver tissues of the white-footed mouse (Peromyscus leucopus), an omnivore, were No. 153, 180, and 170. In another study, the ranking of the ICES 7 congeners in (washed) whole-body samples of the wood mouse (Apodemus sylvaticus), an omnivore, were No. $153>138>118>180>$ $28>52,101$ [23].

Summed PCB homologs for each year were compared to known Aroclor-1254 and -1260 homolog patterns [4] in an attempt to gain information about the dominant PCB absorbed and stored by the field mice at the two study sites. Plots of the measured homolog concentrations (as percentage of the total) compared to Aroc- lor-1254 and -1260 formulations are shown in Figure 4 (behind the weir) and Figure 5 (8 $\mathrm{km}$ below the weir). Accumulation of the PCBs by field mice at both sites appears to be dominated more by Aroclor- 1260 than by Aroclor-1254. The distribution of PCB congeners in Aroclor mixtures can be altered considerably by biological processes; however, this effect is greater in animals of higher trophic levels than in animals of lower trophic levels. For animals of a lower trophic status (e.g., omnivore field mice), the composition of PCB congeners remains very similar to the original Aroclor pattern [52].

\section{Conclusion}

The concentrations of PCBs (mostly Aroclor-1260) in whole-body field mice upgradient of a sediment retention structure in LAC are generally low and are not expected to negatively impact field mice population attributes. Various engineering controls employed by LANL upgra-

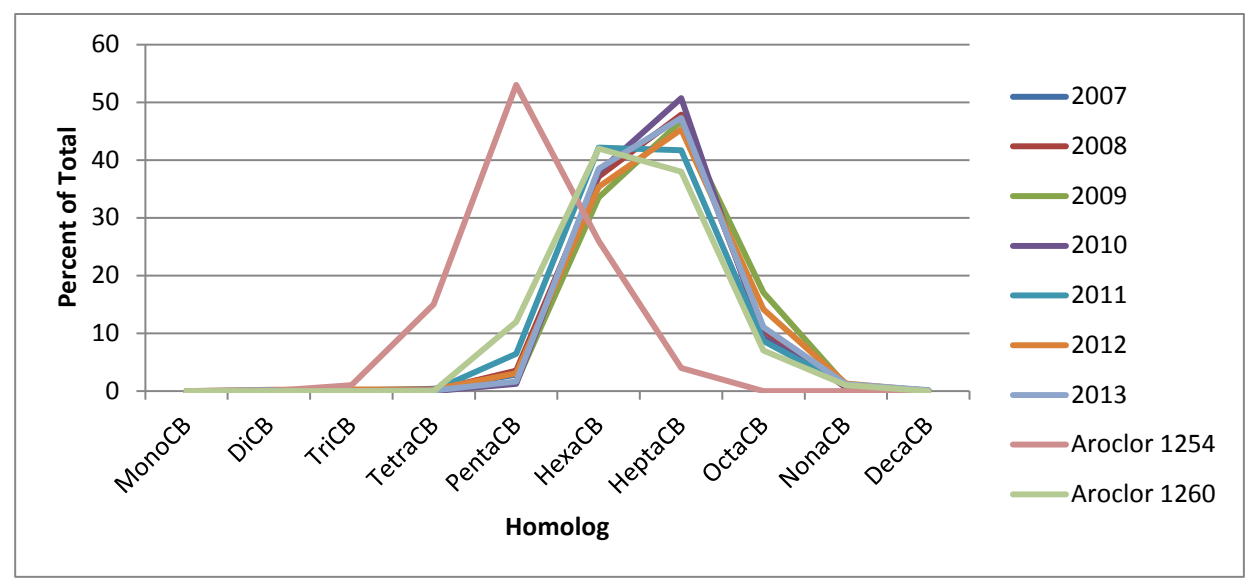

Figure 4. The mean total PCB homolog distribution (as percent of total) for whole-body field mice samples collected directly upgradient of the LAC sediment control structure from 2007 through 2013 as compared with Aroclor-1254 and -1260.

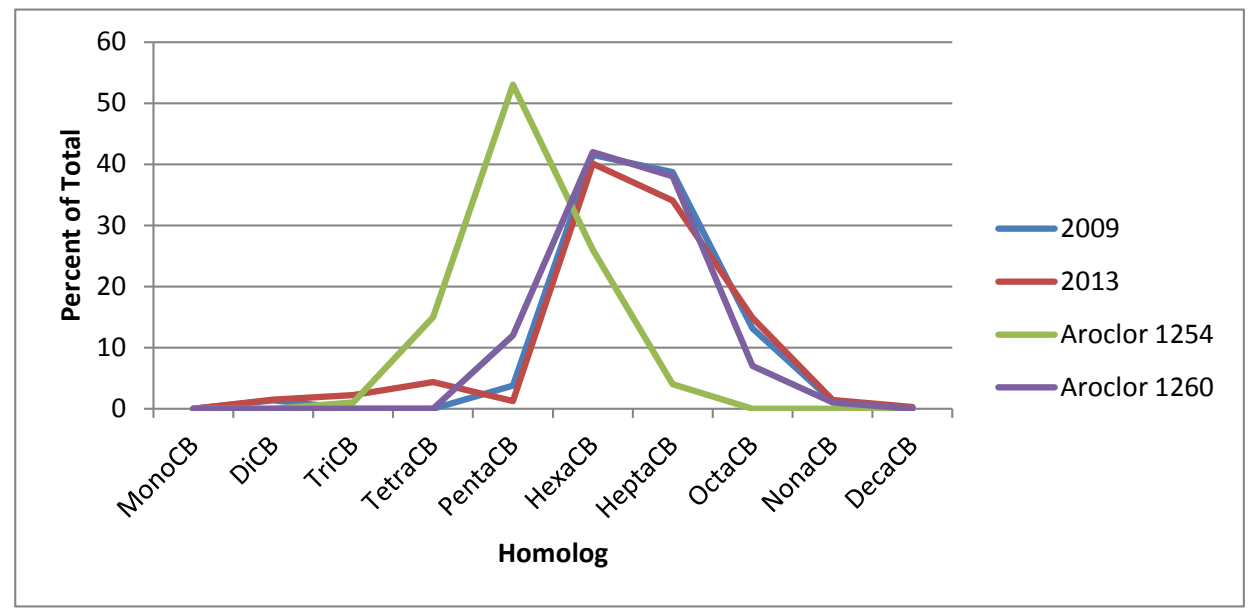

Figure 5. The mean total PCB homolog distribution (as percent of total) for whole-body field mice samples collected $8 \mathrm{~km}$ downgradient of the LAC sediment control structure in 2009 and 2013 as compared with Aroclor-1254 and -1260. 
dient of the LAC weir, at least during this period of study, may have been responsible for the decreasing amounts of PCBs detected in field mice over time. Moreover, the lower amounts of PCBs in field mice further downgradient as compared to upgradient concentrations may be attributed, at least in part, to the reduction of sediment loads by the LAC sediment retention structure. Subsequent flooding events that redistribute and mix various sources of sediment over time and distance from the source may have also have played a role.

\section{Acknowledgements}

Thanks to Rhonda Robinson and Sherri Sherwood of LANL and Raymond Martinez of the Pueblo of San Ildefonso for sample collection of the small mammals; to Winters Redstar for the construction of Figure 1; to Leslie Hanson, Danny Katzman, and Raymond Martinez for a review; and to Teresa Hiteman for editing and composition of the manuscript.

\section{REFERENCES}

[1] K. C. Jones, V. Burnett, R. Duarte-Davidson and K. S. Waterhouse, "PCBs in the Environment," Chemistry in Britain, Vol. 27, 1991, pp. 435-438.

[2] ATSDR, "Public Health Implications of Exposure to Polychlorinated Biphenyls (PCBs),” 2001, CAS\# 1336-36-3.

[3] United States Environmental Protection Agency, "РCB Programs,” 2002. http://www.epa.gov/opptintr/pcb

[4] United States Environmental Protection Agency, "PCBs: Cancer Dose-Response Assessment and Application to Environmental Mixtures,” National Center for Environmental Assessment, Office of Research and Development Report EPA/600/P-96/001F, Washington DC, 1996.

[5] V. A. McFarland and J. U. Clarke, "Environmental Occurrence, Abundance and Potential Toxicity of Polychlorinated Biphenyl Congeners: Considerations for a Conger-Specific Analysis,” Environmental Health Perspectives, Vol. 81, 1989, pp. 225-239. http://dx.doi.org/10.1289/ehp.8981225

[6] J. T. F Ashley and J. E. Baker, "Hydrophobic Organic Contaminants in Surficial Sediments of Baltimore Harbor: Inventories and Sources," Environmental Toxicology and Chemistry, Vol. 18, No. 5, 1999, pp. 838-849.

http://dx.doi.org/10.1002/etc.5620180505

[7] W. H. Burt, "Mammals,” In: R. T. Peterson, Ed., Peterson Field Guide, Houghton Mifflin Company, Boston. 1980, p. 277.

[8] W. J. Arthur, O. D. Markham, C. R. Groves and B. L. Keller, "Radionuclide Export by Deer Mice at a Solid Radioactive Waste Disposal Area in Southeastern Idaho,” Health Physics, Vol. 52, No. 1, 1987, pp. 45-53. http://dx.doi.org/10.1097/00004032-198701000-00004

[9] S. S. Talmage and B. T. Walton, "Small Mammals as Monitors of Environmental Contaminants," Reviews of
Environmental Contamination and Toxicology, Vol. 119, 1991, pp. 47-145. http://dx.doi.org/10.1007/978-1-4612-3078-6 2

[10] P. N. Smith, G. P. Cobb, F. M. Harper, B. M. Adair and S. T. McMurry, "Comparison of White-Footed Mice and Rice Rats as Biomonitors of Polychlorinated Biphenyl and Metal Contamination," Environmental Pollution, Vol. 119, No. 2, 2002, pp. 261-268. http://dx.doi.org/10.1016/S0269-7491(01)00306-2

[11] B. A. Wood, L. Cao and M. D. Dearing, "Deer Mouse (Peromyscus maniculatus) Home-Range Size and Fidelity in Sage-Steppe Habitat," Western North American Naturalist, Vol. 70, No. 3, 2010, pp. 345-354. http://dx.doi.org/10.3398/064.070.0307

[12] S. A. Rudge, M. S Johnson, R. T. Leah and S. R. Jones, "Biological Transport of Radiocaesium in a Semi-Natural Grassland Ecosystem: Small Mammals,” Journal Environmental Radioactivity, Vol. 19, No. 3, 1993, pp. 19-212. http://dx.doi.org/10.1016/0265-931X(93)90003-P

[13] K. Bennett, J. Biggs and P. R. Fresquez, "Radionuclide Contaminant Analysis of Small Mammals, Plants, and Sediments within Mortandad Canyon, 1994,” Los Alamos National Laboratory Report LA-13104-MS, 1996.

[14] P. R. Fresquez, L. Soholt and E. Lopez, "Radionuclide Contaminant Analysis of Small Mammals at Area G, Technical Area 54, 2001 through 2003 (with a Cumulative Summary for 1994 through 2003),” Los Alamos National Laboratory Report LA-14193, 2005.

[15] B. A. Hunter, M. S. Johnson and D. J. Thompson, "Ecotoxicology of Copper and Cadmium in a Contaminated Grassland Ecosystem, III, Small Mammals,” Journal Applied Ecology, Vol. 24, No. 2, 1987, pp. 601-614. http://dx.doi.org/10.2307/2403896

[16] R. F. Shore, "Predicting Cadmium, Lead and Fluoride Levels in Small Mammals from Soil Residues and by Species-Species Extrapolation,” Environmental Pollution, Vol. 88, No. 3, 1995, pp. 333-340. http://dx.doi.org/10.1016/0269-7491(95)93447-8

[17] K. L. Phelps and K. McBee, "Population Parameters of Peromyscus Lecucopus (White-Footed Deer mice) Inhabiting a Heavy Metal Contaminated Superfund Site,” The Southwestern Naturalist, Vol. 55, No. 3, 2010, pp. 363373. http://dx.doi.org/10.1894/MLK-08.1

[18] P. R. Fresquez, L. Hansen and C. Hathcock, "Chemical Concentrations in Field Mice/Voles Collected from an Open-Burn Site at Technical Area 16 at Los Alamos National Laboratory: Revision 2,” Los Alamos National Laboratory Report LA-UR-13-20040, 2013.

[19] K. J. Krouskop, K. C. Ayers and J. L. Proctor, "Multimedia Sampling for Dioxin at a Strip Mine Reclaimed with Sludge from Bleached Kraft Wastewater Treatment," Tappi Journal, Vol. 74, No. 4, 1991, pp. 235-240.

[20] P. R. Fresquez, "Chemical Concentrations in Field Mice Collected from Open-Detonation Firing Sites TA-36 Minie and TA-39 Point 6 at Los Alamos National Laboratory,” Los Alamos National Laboratory Report LA-UR-1110614, 2011.

[21] C. L. Stratton, K. L. Tuttle and J. M. Allan, "Environ- 
mental Assessment of Polychlorinated Biphenyls (PCBs) Near New Bedford, MA, Municipal Landfill," Environmental Protection Agency, Office of Toxic Substances, 560/6-78-006, Washington DC, 1978.

[22] J. Batty, R. A. Leavitt, N. Biondao and D. Polin, “An Ecotoxicological Study of a Population of the WhiteFooted Mouse (Peromyscus leucopus) Inhabiting a Polychlorinated Biphenyls-Contaminated Area," Archives of Environmental Contamination and Toxicology, Vol. 19, No. 2, 1990, pp. 283-290. http://dx.doi.org/10.1007/BF01056098

[23] M. S. Johnson, R. T. Leah, L. Connor, C. Rae and S. Saunders, "Polychlorinated Biphenyls in Small Mammals from Contaminated Landfill Sites,” Environmental Pollution, Vol. 92, No. 2, 1996, pp. 185-191. http://dx.doi.org/10.1016/0269-7491(95)00096-8

[24] K. E. Johnson, L. D. Knopper, D. C. Schneider, C. A. Ollson and K. J. Reimer, "Effects of Local Point Source Polychlorinated Biphenyl (PCB) Contamination on Bone Mineral Density in Deer Mice (Peromyscus maniculatus)," Science Total Environment, Vol. 407, No. 18, 2009, pp. 5050-5055.

http://dx.doi.org/10.1016/j.scitotenv.2009.06.004

[25] D. R. Clark Jr., K. S. Foerster, C. M. Marn and R. L. Hothem, "Uptake of Environmental Contaminants by Small Mammals in Pickleweed Habitats at San Francisco Bay, California," Archives of Environmental Contamination and Toxicology, Vol. 22, No. 4, 1992, pp. 389-396. http://dx.doi.org/10.1007/BF00212559

[26] A. V. Linzey, "Effects of Chronic Polychlorinated Biphenyls Exposure on Reproductive Success of WhiteFooted Mice (Peromyscus leucopus)," Archives of Environmental Contamination and Toxicology, Vol. 16, No. 4, 1987, pp. 455-460.

http://dx.doi.org/10.1007/BF01055267

[27] A. V. Linzey, "Effects of Chronic Polychlorinated Biphenyls Exposure on Growth and Reproduction of Second Generation White-Footed Mice (Peromyscus leucopus)," Archives of Environmental Contamination and Toxicology, Vol. 17, No. 1, 1988, pp. 39-45. http://dx.doi.org/10.1007/BF01055152

[28] A. V. Linzey and D. M. Grant, "Characteristics of a White-Footed Mouse Population Inhabiting a Polychlorinated Biphenyls Contaminated Site," Archives of Environmental Contamination and Toxicology, Vol. 27, No. 4, 1994, pp. 521-526. http://dx.doi.org/10.1007/BF00214844

[29] G. McCoy, M. F. Finlay, A. Rhone, K. James and G. P. Cobb, "Chronic Polychlorinated Biphenyls Exposure on Three Generations of Old-Field Mice (Peromyscus polionotus): Effects on Reproduction, Growth, and Body Residues," Archives of Environmental Contamination and Toxicology, Vol. 28, No. 4, 1995, pp. 431-435. http://dx.doi.org/10.1007/BF00211624

[30] O. T. Sanders and R. L. Kirpatrick, "Reproductive Characteristics and Corticoid Levels of White-Footed Mice Fed ad libitum and Restricted Diets Containing a Polychlorinated Biphenyl, Environmental Research, Vol. 13, No.
3, 1977, pp. 358-363.

http://dx.doi.org/10.1016/0013-9351(77)90015-9

[31] W. D. Purtymun, "Storm Runoff and Transport of Radionuclides in DP Canyon, Los Alamos County, New Mexico,” Los Alamos Scientific Laboratory Report LA5744, 1974.

[32] T. E. Hakonson, G. C. White, E. S. Gladney and M. Dreicer, "The Distribution of Mercury, Cesium-137, and Plutonium in an Intermittent Stream at Los Alamos,” Journal of Environmental Quality, Vol. 9, No. 2, 1980, pp. 289292.

http://dx.doi.org/10.2134/jeq1980.0047242500090002002 $\underline{6 x}$

[33] B. M. Gallaher and D. E. Efurd, "Plutonium and Uranium from Los Alamos National Laboratory in Sediments of the Northern Rio Grande Valley,” Los Alamos National Laboratory report LA-13974, 2002.

[34] S. L. Reneau and R. J. Koch, "Watershed Monitoring," In: Environmental Surveillance at Los Alamos during 2007, Los Alamos National Laboratory Report LA-14369-ENV, 2008.

[35] B. Gallaher, "Watershed Monitoring,” In: Environmental Surveillance at Los Alamos during 2006, Los Alamos National Laboratory Report LA-14341-ENV, 2007.

[36] Los Alamos National Laboratory, "Los Alamos and Pueblo Canyons Investigation Report,” Los Alamos National Laboratory Report LA-UR-04-2714, 2004.

[37] Los Alamos National Laboratory, "Interim Measure Work Plan to Mitigate Contaminated Sediment Transport in Los Alamos and Pueblo Canyons,” Los Alamos National Laboratory Report LA-UR-08-1071, 2008.

[38] W. V. Abeele, M. L. Wheeler and B. W. Burton, "Geohydrology of Bandelier Tuff,” Los Alamos Scientific Laboratory Report, LA-8962-MS, 1981.

[39] S. R. Ellis, G. W. Levings, L. F. Carter, S. F. Richey and M. J. Radell, "Rio Grande Valley, Colorado, New Mexico, and Texas," Journal of the American Water Resources Association, Vol. 29, No. 4, 1993, pp. 617-646. http://dx.doi.org/10.1111/j.1752-1688.1993.tb03230.x

[40] P. R. Fresquez, D. H. Kraig, M. A. Mullen and L. Naranjo Jr., "Radionuclides and Trace Elements in Fish Collected Upstream and Downstream of Los Alamos National Laboratory and the Doses to Humans from the Consumption of Muscle and Bone," Journal of Environmental Science and Health, Vol. 34, No. 5, 1999, pp. 885-899. http://dx.doi.org/10.1080/03601239909373233

[41] G. J. Gonzales and P. R. Fresquez, "Polychlorinated Biphenyls (PCBs) in Catfish and Carp Collected from the Rio Grande Upstream and Downstream of Los Alamos National Laboratory: Revision 1,” Los Alamos National Laboratory Report, LA-14362, 2008.

[42] United States Department of Energy, "Special Environmental Analysis for the Department of Energy, National Nuclear Security Administration, Actions Taken in Response to the Cerro Grande Fire at Los Alamos National Laboratory,” Los Alamos Area Office, DOE/SEA-03, Los Alamos, 2000. 
[43] P. R. Fresquez, "The Characterization of Biotic and Abiotic Media Upgradient and Downgradient of the Los Alamos Canyon Weir: Revision 1,” Los Alamos National Laboratory Report LA-14308, 2006.

[44] P. R. Fresquez, C. Hathcock, J. Fair and D. Keller, "Foodstuffs and Biota Monitoring,” In: Environmental Surveillance at Los Alamos during 2012, Los Alamos National Laboratory Report LA-UR-13-27065, 2013.

[45] J. N. Mills, T. L. Yates, J. E. Childs, R. R. Parmenter, T. G. Ksiazek, P. E. Rollin and C. J. Peters, "Guidelines for Working with Rodents Potentially Infected with Hantavirus," Journal of Mammalogy, Vol. 76, No. 3, 1995, pp. 716-722. http://dx.doi.org/10.2307/1382742

[46] J. R. Biggs and K. Bennett, “Application of Guidelines for Reduction of Hantavirus Infection to Field Studies of Rodent Populations in Northern New Mexico,” Los Alamos National Laboratory Report LA-UR-95-1471, 1995.

[47] P. R. Fresquez, "The Concentration of Radionuclides, Heavy Metals and Polychlorinated Biphenyls in Field Mice Collected from Regional Background Areas: Revision 2," Los Alamos National Laboratory Report LA-UR-
13-28998, 2013.

[48] Los Alamos National Laboratory, "ECORSK Database: Version 2.5,” Los Alamos National Laboratory Report, LA-UR-10-02042, 2010.

[49] Los Alamos National Laboratory, "Environmental Report 2012 Summary,” Los Alamos National Laboratory Report, LA-UR-13-26789, 2013.

[50] International Council for the Exploration of the Sea, "Report of the Advisory Committee on Marine Pollution, 1985,” ICES Report No. 135, 1986, 82 p.

[51] V. Lang, "Polychlorinated Biphenyls in the Environment," Journal of Chromatography A, Vol. 595, No. 1-2, 1992, pp. 1-43. http://dx.doi.org/10.1016/0021-9673(92)85144-I

[52] P. J. Sather, J. M. G. Ikonomou, R. F. Addison, T. He, P. S. Ross and B. Fowler, "Similarity of an Aroclor-Based and a Full Congener-Based Method in Determining Total PCBs and a Modeling Approach to Estimate Aroclor Speciation from Congener-Specific PCB Data," Environmental Science and Technology, Vol. 35, No. 24, 2001, pp. 4874-4880. http://dx.doi.org/10.1021/es010921p. 